第 17 回 日本臨床薬理学会 1996 年 11 月 $1 \sim 2$ 日 東京・京王プラザホテル

\title{
CYP2C19 遺伝的多型と S -メフェニトイン代謝多型の関係
}

$\begin{array}{lll}\text { 久保田 } & \text { 隆 } & \text { 廣*1 千 葉 } \\ \text { 石 崎 } & \text { 高 } & \text { 寛*3 } \\ \end{array}$

目的

CYP2C19 の薬理遺伝的多型は S-メフェニ トインタイプともよばれ、欧米人に比し東洋人 に欠損者、つまり poor metabolizer (PM: 18 - $23 \%$ ）がはるかに多く存在する”。CYP2C19 により代謝される薬物としては、ジアゼパム 2)、イミプラミン³、オメプラソ゚ール4) など臨 床的に重要な薬物が知られており、これら薬物 治療の際、PM の頻度が高い本邦において考慮 すべき点であろう。また、新薬開発において も、遺伝的多型の薬物代謝への影響を評価する ことは、上記の理由から極めて重要と考えられ る。

これまで CYP2C19 の遺伝的多型解析は、フ エノタイプ1) 法が用いられてきた。この手法は それぞれの薬物についての詳細な動態パラメー ターが得られるなど利点が多い。しかし、当然 のことながら経口投与を必要とし、また、服用 の際の時間的拘束をうけるなど煩雑な部分もあ る。一方、最近になって CYP2C19 の exon 4 (m2) と exon $5(m 1)$ 点突然変異を解析す

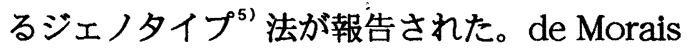
$ら^{5)}$ によると、日本人においては、m1、m2 の遺伝子解析を行うことで PM の $100 \%$ が説 明できると報告している。ジェノタイプ法は、

*1 エスアールエル遺伝子・染色体解析センター 广 192 八王子市小宮町 51

*2 千葉大学楽学部

*3 国立国際医療センター研究所臨床楽理
個々の遺伝子解析に必要となる血液等のサンプ リングが可能であれば、時間的拘束をうけるこ ともなく、多人数の解析も容易である。

そこで今回、我々は CYP2C19のジェノタイ プ法を確立し、日本人におけるその遺伝的多型 の出現頻度を調べるとともに S-メフェニトイ ンの代謝多型（フェノタイプ）解析を行い、相 関関係を検討した。

\section{方法}

（1）対象：健常人 186 名を対象に行った。

（2）ジェノタイプ: 血液より抽出した DNA を用い、CYP2C19 野生型（wt）、2 力 所の点突然変異 $(m 1 、 m 2)$ の解析を de Morais $ら^{5)}$ の方法を一部修正 ${ }^{6)}$ し、PCRRFLP 法を用いて行った。制限酵素処理には m1、m2 に対してそれぞれ Msp I、Bam HI を 使用した。
(3) フェノタイプ:
（2）における 186 名

Tab.1 Genotype analysis of 186 Japanese subjects with respect to the CYP2C19 gene

\begin{tabular}{lcc}
\hline Genotype $*$ & No. of subjects & $\%$ of subjects \\
\cline { 2 - 3 }$w t / w t$ & 65 & 34.9 \\
$w t / m 1$ & 63 & 33.9 \\
$w t / m 2$ & 23 & 12.4 \\
$m 1 / m 2$ & 20 & 10.8 \\
$m 1 / m 1$ & 12 & 6.4 \\
$m 2 / m 2$ & 3 & 1.6 \\
\hline$*$ wt, wild-type; $m 1$, crp2C19 mutation in exon $5 ; m 2$, CYP2C19 \\
mutation in exon 4.
\end{tabular}


Tab.2 Genotype analysis of 46 Japanese subjects with respect to the CrP2C19 gene who were phenotyped with racenic mephenytoin.

\begin{tabular}{|c|c|c|c|}
\hline Genotype * & No, of extensive metabolizers & No. of poor metabolizers $\$$ & Urinary $4^{\prime}$-hydroxymephenytoin ( 8 dose $)$ \\
\hline$w t / w t$ & 23 & 0 & $34.44 \pm 7.08$ \\
\hline$w t / m I$ & 11 & 0 & $32.78 \pm 5.41$ \\
\hline$w t / m 2$ & $\mathbf{5}$ & 0 & $34.39 \pm 5.03$ \\
\hline$m 1 / m 2$ & $\theta$ & 4 & $1.13 \pm 0.69$ \\
\hline$m 1 / m 1$ & 0 & 2 & $0.65,1.86$ \\
\hline$m^{2} / m^{2}$ & 0 & 1 & 1.15 \\
\hline
\end{tabular}

のうち 46 名を対象に $100 \mathrm{mg}$ ラセミ型メフェ ニトインを単回経口投与した後、8 時間尿中代 謝物（4'-ヒドロキシメフェニトイン）を定量す ることにより調べた。投与量に対して排泄され た代謝物のモル濃度の割合（\%）の常用対数

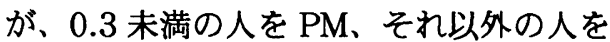
extensive metabolizer (EM) とした。

\section{結果および 考察}

ジェノタイプされた 186 名の各遺伝型頻度は $w t / w t: 34.9 \%$ wt $/ \mathrm{m} 1: 33.9 \%$ wt $/ \mathrm{m} 2$ : $12.4 \% 、 \mathrm{~m} 1 / \mathrm{m} 2: 10.8 \% 、 \mathrm{~m} 1 / \mathrm{m} 1: 6.4 \%$ 、そ して $\mathrm{m} 2 / \mathrm{m} 2: 1.6 \%$ であった（Tab.1）。この ように、日本人において多くの割合をしめる遺 伝型は、CYP2C19 wt と $m 1$ または $m 2$ との ヘテロ接合体 $(46.3 \%)$ であることが判った。

また、フェノタイプされた 46 名のうち PM と判定された 7 名のジェノタイプは、変異型 （m1/m1: 2 名、 $m 2 / m 2: 1$ 名）、もしくは exon 4、exon 5 双方ともにへテロ接合体 （m1/m2: 4 名）であった。一方、 $\mathrm{EM}$ と判定 された 39 名のそれは、野性型（wt/wt: 23 名）、もしくは exon 4、exon 5 のいずれかが ヘテロ接合体（wt/m1: 11 名、wt/m2: 5 名）

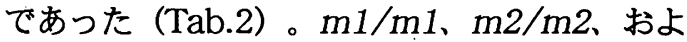
び $m 1 / m 2$ の遺伝型が PM であることから、 CYP 2C19 において、今回解析した日本人の PM の出現頻度は $18.8 \%$ であることが判っ た。

\section{結論}

日本人の $C Y P 2 C 19$ の薬理遺伝的多型は以下 のように結論される。 $m 1$ と $m 2$ の出現頻度 は、それぞれ 0.29、0.13であり、 $\mathrm{m} 1$ の出現 頻度は、m2の 2.2 倍である。また、ジェノ夕 イプとフェノタイプが一致したことから、ジェ ノタイプは CYP2C19 で代謝される薬物の PM、EM の臨床的スクリーニングに有用な方 法と考えられる。

\section{文献}

1) Y. Horai, M. Nakano, T. Ishizaki, K. Ishikawa, H-H. Zhou, B-J. Zhou, C-L. Liao, and L-M. Zhang., Clin.Pharmacol.Ther., 46 (1989) 198.

2 ) D-R. Sohn, M. Kusaka, T. Ishizaki, S-G. Shin, I-J. Jang, K. Chiba., Clin.Pharmacol.Ther., 52 (1992) 160.

3 ) E. Koyama, D-R. Sohn, S-G. Shin, K. Chiba, J-G. Shin, and Y-H. Kim., J.Pharmacol.Exp.Ther., 271 (1994) 860.

4) I. Ieiri, T. Kubota, A. Urae, M. Kimura, Y. Wada, K. Mamiya, S. Yoshioka, S. Irie, T. Amamoto, K. Nakamura, S. Nakano, and S. Higuchi., Clin.Pharmacol.Ther., 59 (1996) 647.

5 ) SMF. de Morais, G-R. Wilkinson, J. Blaisdell, K. Nakamura, U-A. Mayer, and J-A. Goldstein., Mol.Pharmacol., 46 (1994) 594.

6 ) T. Kubota, K. Chiba, and T. Ishizaki., Clin.Pharmacol.Ther., (1996) in press. 